\title{
Evaluation of some microbial agents, natural and chemical compounds for controlling tomato leaf miner, Tuta absoluta (Meyrick) (Lepidoptera: Gelechiidae)
}

\author{
Nesreen M. Abd El-Ghany*, Atef Sayed Abdel-Razek, \\ Ibrahim M.A. Ebadah, Youssf A. Mahmoud
}

Pests and Plant Protection Department, Agricultural and Biological Research Division, National Research Centre, 33 El-Behous St., Dokki, Giza, 12622, Egypt

Received: May 16, 2016

Accepted: October 28, 2016

\begin{abstract}
Solanaceous plants have a great economic impact in Egypt. These groups of plants include potatoes, tomatoes and eggplants. The new invasive pest of tomatoes, Tuta absoluta (Meyrick) causes the greatest crop losses which can range from 60 to $100 \%$. After its detection in Egypt during the last half of 2009, it spread quickly to all provinces in the country. We aiming to propose a sustainable control program for this devastating pest. In this research we tested three groups of control agents. The first was microbial and natural, the second - plant extracts and the third - chemical insecticides. Our results showed that the impact of T. absoluta can be greatly reduced by the use of sustainable control measures represented by different insecticide groups. Bioassay experiments showed that this devastating pest can be controlled with some compounds that give high mortality rates. Of these compounds, spinosad and Beauveria bassiana, microbial control agents, followed by azadirachtin, gave the best results in controlling T. absoluta. Of the chemical insecticides, lambda-cyhalotrin was the most effective, followed by lufenuron and profenofos. In conclusion we encourage farmers to use microbial and natural control measures in combating the tomato leafminer, T. absoluta, in Integrated Pest Mangement (IPM) programs.
\end{abstract}

Key words: biopesticides, IPM programs, natural insecticides, tomato leaf miner

\section{Introduction}

The tomato leaf miner, Tuta absoluta (Meyrick) (Lepidoptera: Gelechiidae) is considered to be one of the most serious pests of tomatoes all over the world. The female adults lay their eggs on different parts of the plant and even on the tomato fruits themselves when there is heavy infestation (Eppo 2005). The damage to tomato crops comes from hatched larvae feeding on the vegetative parts of the tomato plant, causing delayed plant growth. In severe infestation the larvae can attack the tomato fruits (Caceres 1992; Cely et al. 2006). In some countries such as Spain and Brazil, tomato crop losses due to infestation by this pest has reached up to $90 \%$ (Korycinska and Moram 2009). This pest has 10-12 generations per year (Mahmoud et al. 2015).

The control strategies of this pest are mainly based on using chemical insecticides. The crops are sprayed several times during the plantation period, leading to resistance to these chemical insecticides in many countries (Siqueira et al. 2000; Torres et al. 2002). Additionally, these chemical insecticides cause adverse environmental effects including water pollution, eradication of beneficial wildlife and human health problems (Abd El-Ghany et al. 2016). In this research, three groups of control agents were evaluated. The first group included different biopesticides such as, Bacillus thuringiensis (Bt), Beauveria bassiana, Heterorhabditis bacteriophora, and spinosad. The second group included natural plant extracts, garlic, neem and green miracle. The third group included trade formulations of the most popular chemical insecticides used against this pest i.e. lufenuron, profenofos, lambda-cyhalotrin, cyfluthrin.

The aim of this research was the selection of the most effective and safest group that could be used in controlling this pest alone or even in Integrated Pest Management (IPM) programs as a safe and ecofriendly alternative to the hazards of chemical insecticides.

\section{Materials and Methods}

Insects

Tomato plants were grown in a greenhouse at National Research Centre in pots ( $20 \mathrm{~cm}$ diam.) with fertilized soil. They were watered three times a week. These studies were done in the Laboratory of Microbial Control, National Research Centre, Egypt. The colonies of T. absoluta had been reared with tomato leaves under laboratory 
conditions $\left[25 \pm 1^{\circ} \mathrm{C} ; 60 \pm 5 \%\right.$ relative humidity $(\mathrm{RH})$, photoperiod: $14: 10 \mathrm{~h}(\mathrm{~L}: \mathrm{D})]$.

\section{Compounds evaluated}

In these studies three different groups (microbial, natural plant extracts and chemical) of insecticides were evaluated against T. absoluta larvae inside and outside the mines. The first group included nine different biopesticides (Bt subsp. kurstaki, Bt subsp. entomocidus, combination of Bt subsp. kurstaki + entomocidus, Bt subsp. aizawai, spinosad, B. bassiana, H. bacteriophora, azadirachtin and M-Pede. Three concentrations of each of the mentioned agents were used. For Bt preparations, 0.02, 0.01, and $0.005 \mathrm{~g} \cdot \mathrm{l}^{-1}$ were used. Spinosad concentrations were 0.6 , 0.3 and $0.15 \mathrm{~cm}^{3}$. Concentrations of $5 \times 10^{5}, 2.5 \times 10^{5}$ and $1.25 \times 10^{5}$ spore $\cdot \mathrm{m}^{-2}$ were prepared for $B$. bassiana and $5 \times 10^{5}, 2.5 \times 10^{5}$ and $1.25 \times 10^{5} \mathrm{IJ} \cdot \mathrm{m}^{-2}$ for H. bacteriophora. For azadirachtin concentrations of $1.0,0.5$ and $0.25 \mathrm{ml}$. $\cdot \mathrm{l}^{-1}$ were used. M-Pede concentrations were $3.65,1.88$ and $0.94 \mathrm{ml} \cdot \mathrm{l}^{-1}$. The second group included combinations of water plant extracts from garlic + neem + green miracle $(1$ : $: 2: 1)$ and from garlic + basil $(2: 1)$. The concentrations of the first combination were, $1.0,0.1,0.05 \mathrm{ml} \cdot \mathrm{l}^{-1}$ followed by $3.0,1.5,0.75 \mathrm{ml} \cdot \mathrm{l}^{-1}$ for the second combination of garlic + basil water extracts. The third one included trade formulations of the most popular chemical insecticides used against this pest i.e. lufenuron $\left(1.0,0.75,0.5 \mathrm{ml} \cdot \mathrm{l}^{-1}\right)$, profenofos $\left(4.0,3.0,2.0 \mathrm{ml} \cdot \mathrm{l}^{-1}\right)$, lambda-cyhalothrin $(2.5,1.25$, $\left.0.63 \mathrm{ml} \cdot \mathrm{l}^{-1}\right)$ and cyfluthrin $\left(0.5,0.25,0.125 \mathrm{ml} \cdot \mathrm{l}^{-1}\right)$.

\section{Biopesticides}

1) Bacillus thuringiensis subsp. kurstaki $\left[\mathrm{DiPe}^{\circledR} 2 \mathrm{X} \mathrm{DF}\right.$, wettable powder containing the HD-1 isolate with 32,000 international units (IU) $\cdot \mathrm{mg}^{-1}$, Nufarm];

2) Bacillus thuringiensis subsp. entomocidus (an isolate HD-635 obtained from H.D. Dulmage collection in Egypt);

3) Bacillus thuringiensis subsp. kurstaki + entomocidus;

4) Bacillus thuringiensis subsp. aizawai (2014-XEN-0001 XenTari, form 04-7782-R9, CA \& NY from Valent BioSciences Corporation);

5) spinosad $\left(\right.$ Tracer $^{\circledR}$, suspension concentrate, $480 \mathrm{~g} \cdot \mathrm{l}^{-1}$, Dow AgroSciences, Franco da Rocha, SP, Brazil);

6) Beauveria bassiana (Bio-Power, $1 \times 10^{9} \mathrm{cfu} \cdot \mathrm{ml}^{-1}$, T-Stanes \& Company Limited);

7) Heterorhabditis bacteriophora (an entomopathogenic Egyptian nematode isolate);

8) azadirachtin (Nimbecidine ${ }^{\circledR}$ EC, cold pressed, $0.03 \%$, T-Stanes \& Company Limited);

9) M-Pede (M-Pede ${ }^{\circledR}$ Insecticide Miticide Fungicide, potassium salts of fatty acids, 49\%, Gowan Company, USA).

\section{Natural compounds}

Water extracts of crop products from these plants were prepared:

1) garlic + neem + green miracle;

2) garlic + basil.

\section{Chemical insecticides}

1) lufenuron $\left(\right.$ Match $^{\circledR}$, emulsifiable concentrate, $200 \mathrm{~g} \cdot \mathrm{l}^{-1}$, Syngenta Crop Protection Limited);

2) profenofos $\left(\right.$ Celeron $^{\circledR}$, emulsifiable concentrate, Excel Crop Core Ltd., Maharashtra);

3) lambda-cyhalothrin (Lambda Select ${ }^{\mathrm{TM}}$, synthetic pyrethroid, emulsifiable concentrate, $13.0 \%$, Syngenta Group Company);

4) cyfluthrin (Bulldock ${ }^{\circledR} 25$ EC, synthetic pyrethroid, emulsifiable concentrate, beta-cyfluthrin $25 \mathrm{~g} \cdot \mathrm{l}^{-1}$, Bayer, Germany).

\section{Bioassay studies}

Fresh tomato leaves from greenhouse plants were sprayed with three concentrations of each of the previously mentioned agents from the three groups. The leaves were left for a few minutes to dry, and then introduced to the third instar larvae of T. absoluta. Control groups were sprayed with water alone.

Three independent replicates for each bioassay (10 larvae/replicate) were done. After treatments, the larvae were placed in $15 \mathrm{~cm}^{3}$ glass Petri dishes in a controlled environment room at $25 \pm 1^{\circ} \mathrm{C}, 60-70 \%$ relative humidity (RH) with a photoperiod of $14: 10 \mathrm{~h}(\mathrm{~L}: \mathrm{D})$. Mortality was recorded $24 \mathrm{~h}$ after treatment under a stereoscopic microscope $(10 \times)$. Larvae were considered as dead when they were not able to move back to the ventral position after being placed on their dorsum.

\section{Statistical analysis}

Mortality percentages were reported and corrected according to Abbott (1925). The median lethal concentrations $\mathrm{LC}_{50}$ of each tested compound were computed through probit analysis within $95 \%$ confidence limits using the Propan program.

\section{Results}

The data in Figure 1 show that larval mortality percentages of all tested bioagents (microbial and natural) were higher outside the mines than inside them, where the larval mortality percentages of spinosad ranged from 84 to $92 \%$ inside the mines in comparison to approximately 80 to $100 \%$ outside the mines at concentrations of $0.15,0.3$, and $0.6 \mathrm{ml} \cdot \mathrm{1}^{-1}$. Entomopathogenic fungus, B. bassiana, was second. Its larval mortality ranged from 20 to $60 \%$ inside the mines and 33 to $83 \%$ outside the mines. Larval mortality of the entomopathogenic nematode, $\mathrm{H}$. bacteriophora, was similar and had approximately the same percentages inside the mines, while outside the mines the larval mortality percent ranged from 47 to $53 \%$ at the two highest concentrations only. On the other hand, larval mortality percentages did not exceed $60 \%$ either inside or outside the mines with all the tested strains of B. thuringiensis. Moreover, the very weak mortality effect of different strains of $B t$ was more pronounced inside the mines than outside where it reached zero percent inside the mines with $B$. thuringiensis subsp. aizawai while the larval 
mortality percentages of the other three tested Bt strains did not exceed $50 \%$ inside the mines. This percent was recorded with the combination of two strains of B. thuringiensis subsp. kurstaki + subsp. entomocidus, at the higher concentration of $0.02 \mathrm{mg} \cdot \mathrm{l}^{-1}$. A higher mortality percent was obtained with M-Pede ${ }^{\circledR}(100 \%$ mortality) at its higher concentration outside the mines. On the other hand, azadirachtin gave the highest larval mortality percent (92\%) of all tested natural compounds inside the mines in comparison to $70 \%$ mortality with M-Pede. In general, both
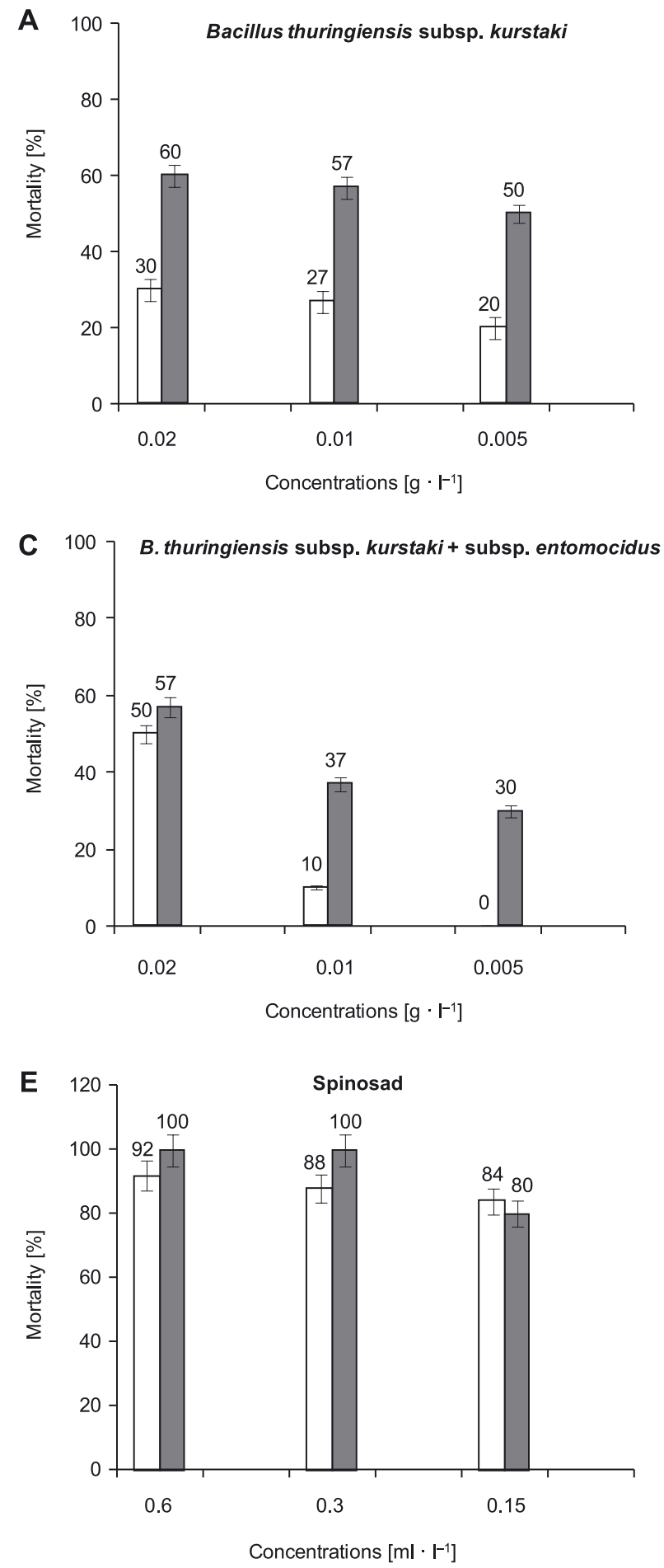

azadirachtin and M-Pede were the most effective natural compounds against the larval stage of T. absoluta both inside and outside the treated mines.

Moreover, the $\mathrm{LC}_{50}$ for the mentioned microbial agents inside and outside the mines were calculated (Table 1). The data of $\mathrm{LC}_{50}$ for different $B t$ strains indicate that, the conjugated effects of both $B$. thuringiensis subsp. kurstaki + subsp. entomocidus gave the lowest $\mathrm{LC}_{50}$ value compared with individual strains. Furthermore, there were significant differences inside and outside mines between each
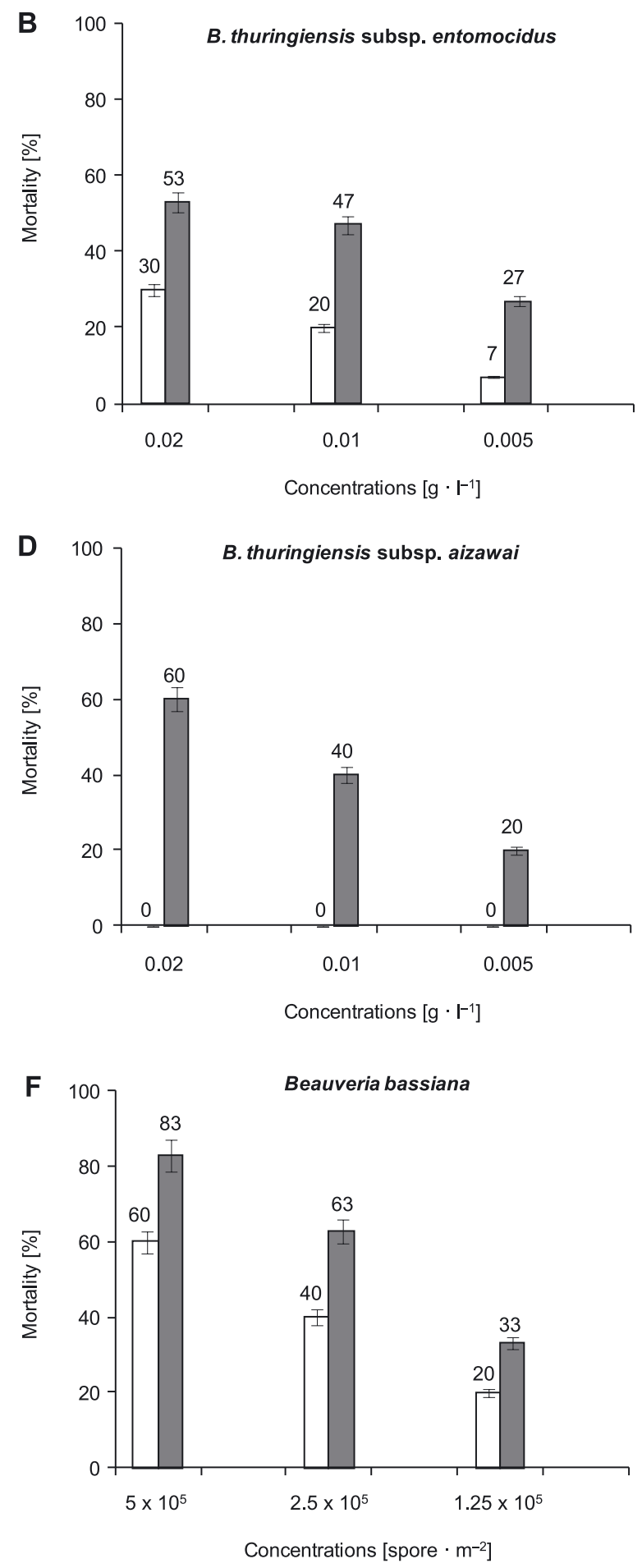

Corrected $\%$ mortality of larvae outside mines

Fig. 1. Effects of different microbial control agents (A-I) against tomato leaf miner, Tuta absoluta 

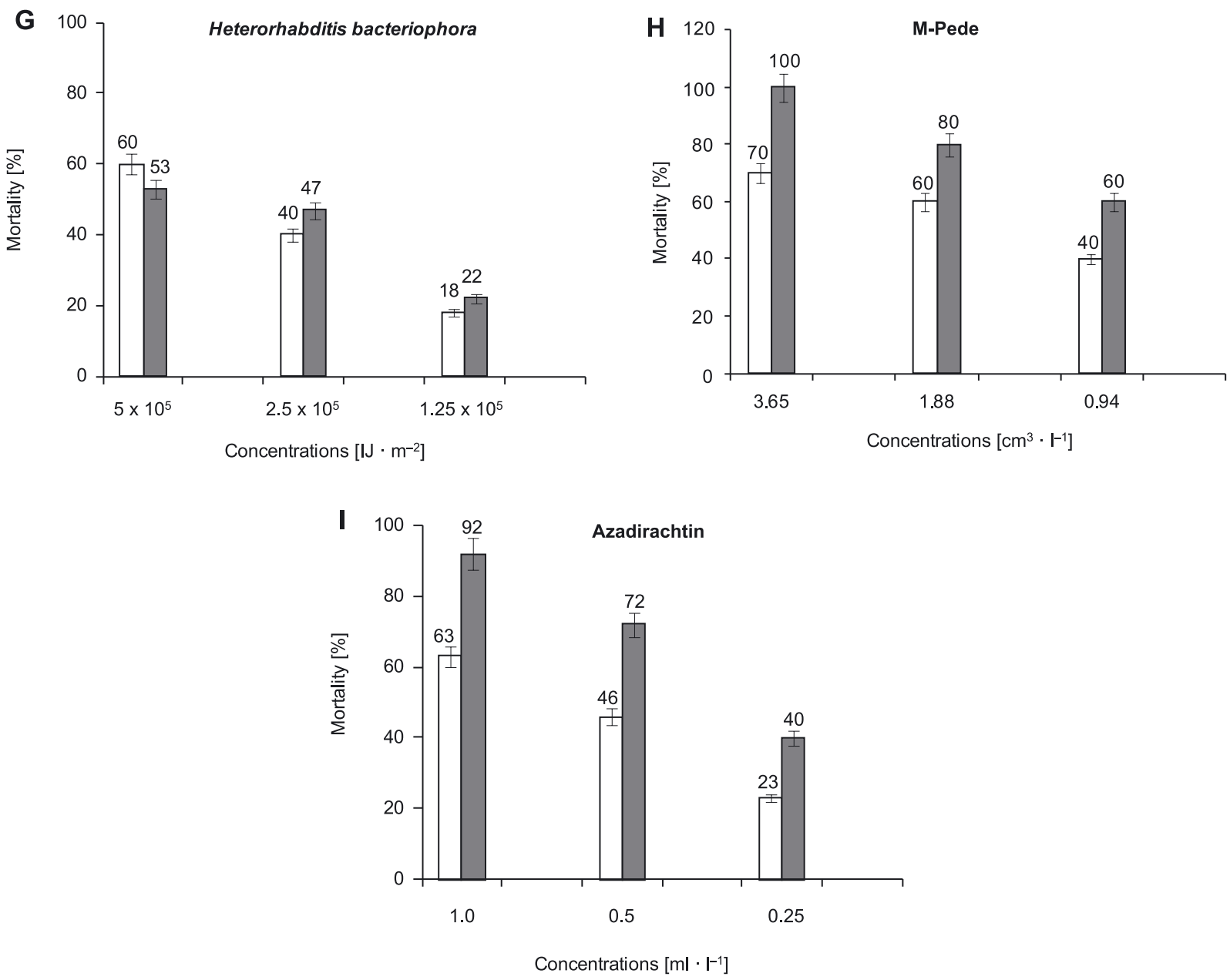

$\square$ Corrected \% mortality of larvae inside mines

Corrected \% mortality of larvae outside mines

Fig. 1. Effects of different microbial control agents (A-I) against tomato leaf miner, Tuta absoluta - continuation

Table 1. $\mathrm{LC}_{50}$ inside and outside mines at confidence limits (95\%) of different microbial, natural and chemical control agents against tomato leaf miner, Tuta absoluta

\begin{tabular}{lcccc}
\hline \multicolumn{1}{c}{ Compound } & $\mathrm{LC}_{50}$ inside mines & Slope $\pm \mathrm{SE}$ & $\mathrm{LC}_{50}$ outside mines & Slope $\pm \mathrm{SE}$ \\
\hline Bacillus thuringiensis subsp. kurstaki & $0.186 \mathrm{~g} \cdot \mathrm{l}^{-1}$ & $1.02 \pm 0.98$ & $0.005 \mathrm{~g} \cdot \mathrm{l}^{-1}$ & $0.86 \pm 0.48$ \\
B. thuringiensis subsp. entomocidus & $0.041 \mathrm{~g} \cdot \mathrm{l}^{-1}$ & $1.72 \pm 1.05$ & $0.0 .015 \mathrm{~g} \cdot \mathrm{l}^{-1}$ & $0.67 \pm 0.76$ \\
B. thuringiensis subsp. kurstaki + entomocidus & $0.019 \mathrm{~g} \cdot \mathrm{l}^{-1}$ & $0.97 \pm 0.86$ & $0.012 \mathrm{~g} \cdot \mathrm{l}^{-1}$ & $1.17 \pm 1.28$ \\
B. thuringiensis subsp. aizawai & 0.00 & 0.00 & $0.014 \mathrm{~g} \cdot \mathrm{l}^{-1}$ & $1.67 \pm 0.28$ \\
Spinosad & $0.14 \mathrm{ml} \cdot \mathrm{l}^{-1}$ & $0.72 \pm 0.40$ & $0.13 \mathrm{ml} \cdot \mathrm{l}^{-1}$ & $0.72 \pm 0.40$ \\
Beauveria bassiana & $3.57 \mathrm{spore} \cdot \mathrm{m}^{-2}$ & $1.81 \pm 0.32$ & $1.89 \mathrm{spore} \cdot \mathrm{m}^{-2}$ & $2.32 \pm 0.33$ \\
Heterorhabditis bacteriophora & $3.53 \mathrm{IJ} \cdot \mathrm{m}^{-2}$ & $1.67 \pm 0.28$ & $3.74 \mathrm{IJ} \cdot \mathrm{m}^{-2}$ & $1.22 \pm 0.27$ \\
M-Pede & $1.37 \mathrm{ml} \cdot l^{-1}$ & $1.33 \pm 0.98$ & $0.83 \mathrm{~cm} \cdot 1^{-1}$ & $3.07 \pm 1.42$ \\
Azadirachtin & $0.62 \mathrm{ml} \cdot l^{-1}$ & $1.76 \pm 0.31$ & $0.31 \mathrm{ml} \cdot 1^{-1}$ & $2.75 \pm 0.36$ \\
Garlic + neem + green miracle & $1.87 \mathrm{ml} \cdot l^{-1}$ & $1.15 \pm 0.83$ & $0.43 \mathrm{ml} \cdot 1^{-1}$ & $1.38 \pm \cdot 28$ \\
Garlic + basil & $10.0 \mathrm{ml} \cdot l^{-1}$ & $2.39 \pm 1.39$ & $5.98 \mathrm{ml} \cdot l^{-1}$ & $0.71 \pm 0.31$ \\
Lufenuron & $0.61 \mathrm{ml} \cdot l^{-1}$ & $2.87 \pm 0.61$ & $0.26 \mathrm{ml} \cdot l^{-1}$ & $1.66 \pm 0.65$ \\
Profenofos & $3.72 \mathrm{ml} \cdot l^{-1}$ & $2.52 \pm 0.68$ & $2.17 \mathrm{ml} \cdot l^{-1}$ & $2.96 \pm 0.74$ \\
Lambda-cyhalothrin & $0.49 \mathrm{ml} \cdot l^{-1}$ & $1.83 \pm 0.35$ & $0.56 \mathrm{ml} \cdot 1^{-1}$ & $3.07 \pm 1.08$ \\
Cyfluthrin & $0.73 \mathrm{ml} \cdot l^{-1}$ & $2.37 \pm 1.39$ & $0.29 \mathrm{ml} \cdot 1^{-1}$ & $1.85 \pm 0.31$ \\
\hline
\end{tabular}


Bt subspecies and conjugated ones. However, no significant differences were found between $\mathrm{LC}_{50}$ values inside and outside the mines for spinosad and H. bacteriophora. The $\mathrm{LC}_{50}$ value outside the mines for B. bassiana is was recorded as 1.89 spore $\cdot \mathrm{m}^{-2}$ which show significant difference than inside mines ( 3.57 spore $\cdot \mathrm{m}^{-2}$ ). Data in Table 1 indicate that there was a significant difference in the $\mathrm{LC}_{50}$ value between larval mortalities inside and outside the mines; the value outside mines was lower $\left(0.83 \mathrm{ml} \cdot \mathrm{l}^{-1}\right)$ than insides mines $\left(1.37 \mathrm{ml} \cdot \mathrm{l}^{-1}\right)$. For azadirachtin, the $\mathrm{LC}_{50}$ values inside and outside the mines were double fold significance as 0.62 and $0.31 \mathrm{ml} \cdot 1^{-1}$, respectively.

Two combinations of of different water plant extracts were evaluated against the larval stage of T. absoluta inside and outside the treated mines (Fig. 2). A higher mortality percent was recorded for a combination of garlic + neem + green miracle extracts, while the combination garlic + basil gave the lowest mortality $(40 \%)$. The $\mathrm{LC}_{50}$ values for a combination of three natural compounds (garlic + neem + green miracle) were also determined and significant differences were found between inside and outside the mines. The lowest potency was recorded for the combination of garlic and basil $10.0 \mathrm{ml} \cdot \mathrm{l}^{-1}$ inside the mines and $5.98 \mathrm{ml} \cdot \mathrm{l}^{-1}$ outside the mines, respectively.

Four widely recommended chemical insecticides were evaluated in controlling T. absoluta (Fig. 3). An evaluation of these insecticides was made to compare their mortality effects with that of both microbial agents and natural compounds. The data revealed that lambda-cyhalothrin insecticide gave the highest larval mortality percentages both inside and outside mines; they ranged from 60 to $100 \%$ and from 60 to $91 \%$, respectively. On the other hand, the lowest larval mortality percentages were recorded with both profenofos and cyfluthrin insecticides inside mines while lufenuron insecticide gave moderate larval mortality percent both inside and outside mines especially at its high concentration.

Concerning $\mathrm{LC}_{50}$ values, of all tested chemical compounds lufenuron was found to be the most potent compound followed by lambda-cyhalothrin. For lufenuron, the $\mathrm{LC}_{50}$ value inside mines was $0.61 \mathrm{ml} \cdot \mathrm{l}^{-1}$, whereas a lower value of $0.26 \mathrm{ml} \cdot 1^{-1}$ was recorded outside the mines. On the other hand, profenofos was the weakest tested compound with a $\mathrm{LC}_{50}$ value of $3.72 \mathrm{ml} \cdot \mathrm{l}^{-1}$ and $2.17 \mathrm{ml} \cdot 1^{-1}$ inside and outside the mines, respectively.

\section{Discussion}

Tomato is one of the most important vegetable crops in Egypt which is considered to be the fifth largest tomato producer in the world (WPTC 2011). In recent years, this crop has been so heavily attacked by the tomato leaf miner, T. absoluta, that some infested areas appeared as a divested desert (Mahmoud et al. 2015). Due to indiscriminate and intensive use of insecticides in controlling this pest, the resistance of T. absoluta to these insecticides has frequently been reported (Salazar and Araya 1997; Siqueira et al. 2000; Salazar and Araya 2001; Abdel-Razek and Abd El-Ghany 2014; Mahmoud et al. 2015). Among various bio-rationale insecticides, B. thuringiensis, Beauveria bassiana, spinosad and azadirachtin are popularly used for controlling many insect pests (Merdan et al. 2010; Salama et al. 2012; AbdelRazek et al. 2014; Abd El-Ghany et al. 2015). This study evaluated the efficacy of different bio-rationale control agents, natural and chemical, for controlling this serious pest alone or even in IPM programs. The results of this research indicated that spinosad exhibited a satisfactory efficacy against the larval stage of T. absoluta inside and outside the treated mines, where all larvae were killed outside the mine in Egypt. Spinosad is used for controlling many lepidopterous pests of vegetable crops (Michaud and Grant 2003; Galva et al. 2005; Gamal et al. 2013). Hilal (2006) suggested that spinosad is very effective in controlling Spodoptera littoralis. The entomopathogenic fungus, B. bassiana, was second in its effectiveness after spinosad. It caused more than $50 \%$ larval mortality outside mines. On the other hand, the lower toxicity effects of different $\mathrm{Bt}$ strains against the larval stage of T. absoluta may be due to the insect rearing behavior and/or higher sensitivity of $\mathrm{Bt}$ to environmental factors such as temperature and relative
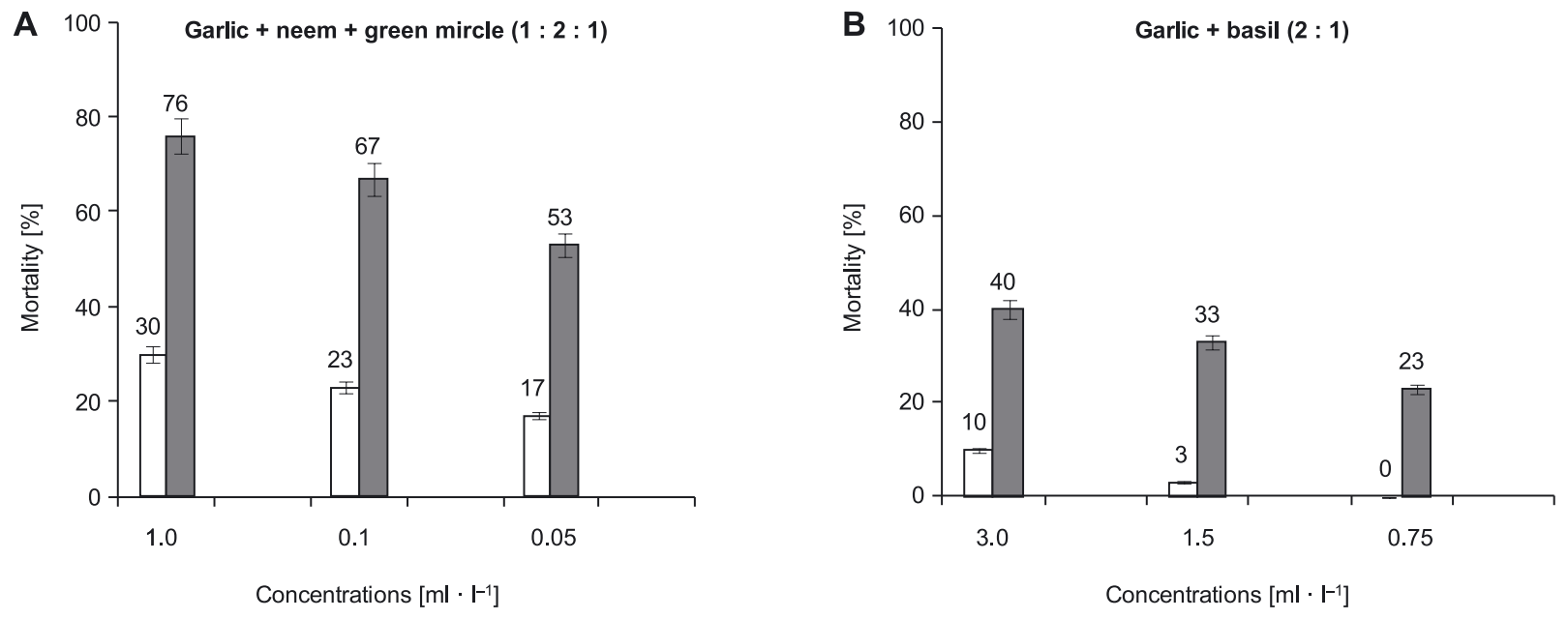

Corrected $\%$ mortality of larvae inside mines

Corrected $\%$ mortality of larvae outside mines

Fig. 2. Effects of different natural control agents (A-B) against tomato leaf miner, Tuta absoluta 

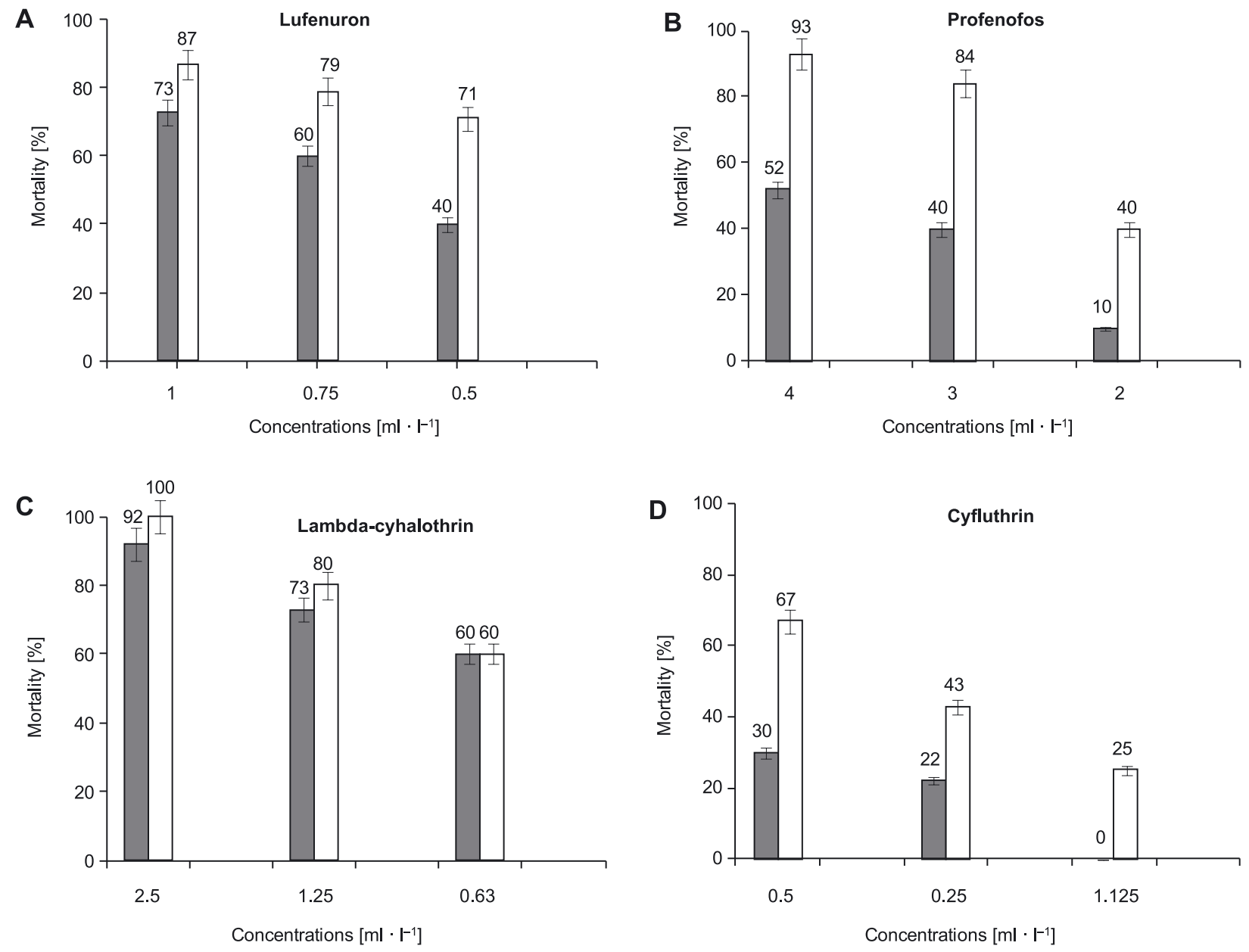

$\square$ Corrected \% mortality of larvae inside mines

Corrected \% mortality of larvae outside mines

Fig. 3. Effects of different chemical insecticides (A-D) against tomato leaf miner, Tuta absoluta

humidity (Khidr et al. 2013). Sow and Diarra (2013) reported that Bt alone is not highly effective as a control measure of lepidopterous pests but it can help and complement integrated control measures.

Biopesticides derived from natural plant extracts, are widely used for controlling many families of insect pests because they are friendly to the environment, humans and natural enemies (Nilahyane et al. 2012; Braham and Hajji 2012; Ghanim and AbdelGhani 2014). The tested natural compounds provided promising results in controlling the larval stage of T. absoluta inside and outside the mines especially azadirachtin and M-Pede. The effects of these two compounds were very similar to the insecticides, and caused almost complete eradication of the larvae while the other two combinations had no larval mortality especially inside mines. Many authors consider neem extract to be an insecticide due to its high toxicity against the target pest (Kleeberg 2001; Isman 2006; Hiiesaar et al. 2009). The high effectiveness of neem extract comes from its mode of action where it can act as a contact and systemic insecticide against the larval stage of T. absoluta (Gerrasio and Vendramin 2007). Yankova et al. (2014) recorded high mortality percentages in early larval stages of T. absoluta even 14 days after the tomato plants had been sprayed.
Chemical insecticides are one of the most common and widely used methods for controlling T. absoluta around the world because they have rapid action and strong toxicity against the target pest. Much research has been done on using chemical insecticides for controlling T. absoluta (Colomo et al. 2002; Molla et al. 2011; Shalaby et al. 2012; Mahmoud et al. 2014; Deleva and Harizanova 2014). Of the tested chemical insecticides lambda-cyhalothrin was the most effective in controlling T. absoluta. It caused complete mortality of the larval stage of $T$. $a b$ soluta inside and outside the treated mines especially at its high concentration. Match was second in effectiveness after lambda-cyhalothrin. It caused $75 \%$ larval mortality outside the mines and more than $50 \%$ inside the mine. The other tested insecticides, profenofos and cyfluthrin showed low mortality effects against $T$. absoluta larvae. Their toxicity on the larvae inside the mines was so minimal that it can be neglected. Mahmoud et al. (2014) stated that lambda-cyhalothrin caused considerable mortality against early larval stages of T. absoluta.

Generally, the results of this research confirmed that spinosad is one of the most effective biological control agents used for controlling T. absoluta. This biological agent can fully protect tomato plants from infestation with T. absoluta. The natural compounds M-Pede or 
Nimbecidine EC can be used alone for controlling T. $a b$ soluta. A comparison of the percentages of larval mortality of the three types of formulations shows that spinosad, M-Pede and Nimbecidine EC can be recommended as very good, safe alternatives for controlling the tomato leaf miner, T. absoluta, especially in IPM Programs.

\section{Acknowledgements}

This study was kindly sponsored by the National Research Centre, Egypt, project No. 9050206.

\section{References}

Abbott W. 1925. A method of computing the effectiveness of an insecticide. Journal of Economic Entomology 18 (2): 265-267.

Abdel-Razek A.S., Abdel Salam A.E., Abd El-Ghany N.M. 2014. Sustainable potato tuber moth, Phthoremia operculella (Zeller), control using biopesticides of natural and microbial origin. African Journal of Agricultural Science and Technology 2 (6): 125-130.

Abdel-Razek A.S., Abd El-Ghany N.M. 2014. Reducing risk of infestation with tomato leaf miner, Tuta absoluta (Meyrick) (Lepidoptera: Gelechiidae) to tomato plants in Egypt. p. 34. In: Proceedings of the 11th Arab Congress of Plant Protection, Amman, Jordan, 9-13 November 2014.

Abd El-Ghany N.M., Abdel Ghany E.M., Salama H.S. 2015. Efficiency of new B. thuringiensis isolates from Egypt against the pink bollworm Pectinophora gossypiella (Saunders). Biopesticides International 11 (1): 12-19.

Abd El-Ghany N.M., Abdel-Wahab E.S., Ibrahim S.S. 2016. Population fluctuation and evaluation the efficacy of pheromone-based traps with different color on tomato leafminer moth, Tuta absoluta (Lepidoptera: Gelechiidae) in Egypt. Research Journal of Pharmaceutical, Biological and Chemical Sciences 7 (4): 1533-1539.

Aydin H., Gürkan M.O. 2006. The efficacy of spinosad on different strains of Spodoptera littoralis (Boisduval) (Lepidoptera: Noctuidae). Turkish Journal of Biology 30 (1): 5-9.

Braham M., Glida-Gnidez H., Hajji L. 2012. Management of tomato borer, Tuta absoluta in Tunisia with novel insecticides and plant extracts. EPPO Bulletin 42 (2): 291-296.

Cáceres S. 1992. La polilla del tomate en Corrientes [The tomato moth in Corrientes]. Biology and Control. Bella Vista Agricultural Experimental Station, INTA, 19 pp. (in Spanish)

Colomo M.V., Berta D.C., Chocobar M.J. 2002. El complejo de himenópteros parasitoides que atacan a la polilla del tomate Tuta absoluta (Lepidoptera: Gelechiidae) en la Argentina [The parasitoids Hymenoptera attacking the tomato moth Tuta absoluta (Lepidoptera: Gelechiidae) in Argentina]. Acta Zoologica Lilloana 46 (1-2): 81-92. (in Spanish, with English summary)

Deleva E.A., Harizanova V.B. 2014. Efficacy evaluation of insecticides on larvae of the tomato borer Tuta absoluta, Meyrick (Lepidoptera: Gelechiidae) under laboratory conditions. Journal of International Scientific Publications: Agriculture and Food 2: 158-164. Available on: http://www.scientificpublications.net. [Accessed: 1 June 2014]

EPPO (European and Mediterranean Plant Protection Organization). 2005. Data sheets on quarantine pests: Tuta absoluta. EPPO Bulletin 35: 434-435.
Galvan T.L., Koch R.I., Hutchison W.D. 2005. Effects of spinosad and indoxacarb on survival, development, and reproduction of the multicolored Asian lady beetle (Coleoptera: Coccinellidae). Biological Control 34 (1): 108-114.

Gamal E., Hanem S., Hagar A., Adel A., Moustafa N. 2013. Sublethal effect of spinosad on the cotton leaf worm (Lepidoptera: Noctuidae). Journal of Plant Protection Research 53 (3): 275-284.

Ghanim N.M., Abdel Ghani S.B. 2014. Controlling Tuta absoluta (Lepidoptera: Gelechiida) and Aphis gossypii (Hemiptera: Aphididae) by aqueous plant extracts. Life Science Journal 11 (3): 299-307.

Goncalves-Gervasio R.C.R., Vendramim J.D. 2007. Bioatividade do extrato aquoso de sementes de nim sobre Tuta absoluta (Meyrick, 1917) (Lepidoptera: Gelechiidae) em três formas de aplicação [Bioactivity the aqueous extract of neem on Tuta absoluta (Meyrick, 1917) (Lepidoptera: Gelechiidae) in three forms application]. Ciência e Agrotecnologia 31 (1): 28-34. (in Spanish, with English summary)

Hiiesaar K., Švilponis E., Metspalu L., Jõgar K., Mänd M., Luik A., Karise R. 2009. Influence of Neem-Azal T/S on feeding activity of Colorado Potato Beetles (Leptinotarsa decemlineata Say). Agronomy Results 7 (1): 251-256.

Isman M.B. 2006. Botanical insecticides, deterrents, and repellents in modern agriculture and an increasingly regulated world. Annual Review of Entomology 51: 45-66.

Khidr A.A., Gaffar S.A., Maha S., Nada A., Taman A., Fathia A., Salem A. 2013. New approaches for controlling tomato leafminer, Tuta absoluta (Meyrick) in tomato fields in Egypt. Egyptian Journal of Agricultural Research 91 (1): 335-348.

Kleeberg H. 2001. Neemazal-T/S a botanical product for efficient control of insect pests. Practice oriented results on use and production of plant extracts and pheromones in integrated and biological pest control. p. 28-35. In: “Practice Oriented Results on Use and Production of Plant Extracts and Pheromones in Integrated and Biological Pest Control". Proceedings of the 2nd Workshop "Neem and Pheromones". University of Uberaba, Brazil, 15-16 May 2001.

Korycinska A., Moran H. 2009. Tuta absoluta, a South American pest of tomato now in the EPPO region: Biology, distribution and damage. EPPO Bulletin 42 (2): 205-210.

Mahmoud Y.A., Salem S.H., Shalaby Sh.E.M., Abdel-Razek A.S., Ebadah I.M.A. 2014. Effect of certain low toxicity insecticides against tomato leaf miner (Tuta absoluta) with reference to their residues in harvested tomato fruits. International Journal of Agriculture Research 9 (4): 210-218.

Mahmoud Y.A., Ebadah I.M.A., Abdel-Razek A.S., Abd-Elwahab T.E., Masry S.H.D. 2015. Population fluctuation of tomato leaf miner, Tuta absoluta (Meyrick) (Lepidoptera: Gelechiidae) during winter and summer plantations in Egypt. Research Journal of Pharmaceutical, Biological, and Chemical Sciences 6 (4): 647-652.

Merdan A., Salama H.S., Labib E., Ragaei M., Abd El-Ghany N.M. 2010. Bacillus thuringiensis isolates from soil and diseased insects in Egyptian cotton fields and their activity against lepidopterous insects. Archives of Phytopathology and Plant Protection 43 (12): 1165-1176.

Michaud J.P., Grant A.K. 2003. IPM-compatibility of foliar insecticides for citrus: indices derived from toxicity to beneficial insects from four orders. Journal of Insect Science 3 (18): $1-10$. 
Molla O., Gonzalez-Cabrera J., Urbaneja J. 2011. The combined use of Bacillus thuringiensis and Nesidiocoris tenuis against the tomato borer Tuta absoluta. Biocontrol 56: 883-891.

Nilahyane A., Bouharroud R., Hormatallah A., Taadaouit N.A. 2012. Larvicidal effect of plant extracts on Tuta absoluta (Lepidoptera: Gelechiidae). IOBC-WRPS Bulletin 80: 305310.

Salama H.S., Saker M., Salama M., El-Banna A., Ragaei M., Abd El-Ghany N.M. 2012. Bacillus thuringiensis isolates from Egyptian soils and their potential activity against lepidopterous insects. Archives of Phytopathology and Plant Protection 45 (7): 856-868.

Salazar E.R., Araya J.E. 1997. Detección de resistencia a insecticidas en la polilla del tomate [Detection of insecticide resistance in tomato moth]. Simiente 67: 8-22.

Salazar E.R., Araya J.E. 2001. Respuesta de la polilla del tomate, Tuta absoluta (Meyrick), insecticidas en Arica [Response of tomato moth, Tuta absoluta (Meyrick), insecticides in Arica. Agricultura Tecnica 61: 429-435.

Shalaby Sh.E.M., Soliman M.M., Abd El-Mageed E.M. 2012. Evaluation of some insecticides against tomato leaf minor (Tuta absoluta) and determination of their residues in tomato fruits. Applied Biological Research 14 (2): 112-118.

Siqueira H.A., Guedes R.N., Picanço M.C. 2000. Insecticide resistance in populations of Tuta absoluta (Lepidoptera: Gelechiidae). Agricultural and Forest Entomology 2: 147-153.

Sow G., Diarra K. 2013. Laboratory evaluation of toxicity of Bacillus thuringiensis, neem oil and methamidophos against Plutella xylostella L. (Lepidoptera: Plutellidae) larvae. International Journal of Biological and Chemical Sciences 6 (4): 1524-1533.

Torres J.B., Evangelista W.S., Barras R., Guedes R.N.C. 2002. Dispersal of Podisus nigrispinus nymphs preying on tomato leafminer: effect of predator release time, density and satiation level. Journal of Applied Entomology 126: 326-332.

WPTC (World Processing Tomato Council). 2011. Report of World Processing Tomato Council, 10 pp.

Yankova V., Valchev N., Makova D. 2014. Effectiveness of phytopesticide Neem Azal T/S ${ }^{\circledR}$ against tomato leaf miner (Tuta absoluta Meyrick) in greenhouse tomato. Bulgarian Journal of Agricultural Science 20 (5): 1116-1118. 